\title{
The Political Economy of Inequality in Chile and Mexico: Two Tales of Neoliberalism
}

\author{
Giorgos Gouzoulis* and Collin Constantine** \\ * University College London; g.gouzoulis@ucl.ac.uk \\ ** SOAS, University of London; constantine.collin@soas.ac.uk
}

\begin{abstract}
This paper undertakes a comparative study on the topographies of neoliberalism in Latin America (Chile and Mexico) and provides empirical estimates of how the varied geographies of neoliberalism affect functional income inequality between 1980-2011. Our empirical strategy employs a single-equation Unrestricted Error-Correction Model that tests an exploratory baseline specification. We find robust evidence that government consumption is a positive driver of the respective wage shares. Since Chile has entrenched austerity as opposed to Mexico, it is a fundamental explanation for its falling wage share. Private debt is the second most important explanation for why wage shares have fallen in Chile. We find no evidence of this channel in the Mexican case. The article also finds similarly varied effects of globalisation on the respective wage shares. These results demonstrate the importance of country-level studies and how new spatialities of neoliberalism through different state reconfigurations can tell unique distributional stories.
\end{abstract}

Keywords: Geographies of neoliberalism; Wage Share; Latin America, Chile; Mexico

\section{Introduction}

Since the latter half of 2019, large street protests against the rising cost of living and 'extreme' inequality have engulfed Latin America (DW 2019). Few examples are Ecuador, Chile, and Argentina. These events call into question the drivers of rising inequalities. Despite political awareness of highincome inequality in South America, only a handful of research focuses on the region, while much of the literature is centred on advanced countries (e.g. Alvarez 2015, Wood 2017, Flaherty and Riain 2019). Rare exceptions are Arestis and Phelps (2019), Onaran (2009), Guschanski and Onaran (2017), and Ibarra and Ross (2019). However, due to poor data availability, these studies only cover the post1990 period and omit the first decade of neoliberalism. This is an important shortcoming, since, as Onaran and Galanis (2014) show, during this period, decreasing wage shares have a significant negative impact on growth in a diverse array of economies, including Argentina and Mexico.

Given this gap, we offer a historical and econometric investigation on the determinants of functional income inequality in Chile and Mexico between 1980-2011, utilising the recently developed wage share dataset of Astorga (2017). Since our data covers the beginning of neoliberalism, the paper identifies the drivers of functional income distribution that are universal and those that depend on 
unique topographies of neoliberalism (Martin 2005). In this article, we choose to examine the cases of Chile and Mexico since they differ in terms of economic and political geographies (Perreault and Martin 2005), which allows us to empirically estimate the distributional effects of varied state reconfigurations.

We present empirical evidence that the roots of the recent Chilean uprising can be found in its extreme neoliberal experiment since the Pinochet regime. In this article, neoliberalism refers to the enactment of pro-capital policies that allow private enterprises to determine what, how and for whom to produce. Consistent with the agenda of 'free markets', the Chilean authorities from dictatorship to democracy have cut welfare expenditure, maintained private ownership/delivery of key public services and undermined labour market institutions that led to an unprecedented accumulation of private debt. Time-series evidence between 1980-2011 suggests that government consumption, private debt, trade openness and terms of trade are statistically significant determinants of functional income distribution in Chile. Four decades of this social experiment have erupted on the streets with recent calls for deep reforms and constitutional amendments, where many neoliberal policies are enshrined.

This article argues that the positive effect of trade globalisation in Chile is related to the external commodity boom experienced by that country, particularly in the 2000s (Sanchez-Ancochea 2019). Higher wage demands are easier to satisfy during periods of high commodity prices. This finding illustrates that the distributional effects of globalisation are not unambiguously negative for the functional income distribution. In fact, it adds empirical support to the Stolper and Samuelson (1941) Theorem - that the more abundant factor - labour in the case of Chile - gains from international trade. The study also finds robust evidence that private debt contracts the wage share in Chile. We envision two channels: 1. Deterioration of firms' balance sheet forces them to cut costs by lowering wages and 2. Higher household debt weakens labour's bargaining power and increases the probability that workers accept lower wages. Further, we find that government consumption has positive and statistically significant effects on the wage share. As it relates to size effects, the evidence suggests that government consumption and private debt are the two more important factors that explain falling wage shares in Chile. This is a striking finding. It demonstrates the imperative of public services and why governments are essential distributional stabilisers even if globalisation proves to be beneficial for income distribution. There is no replacing the role of the Leviathan but this has been the fundamental Chilean experiment.

In contrast, our study of Mexico shows that another world is possible - stable functional income distribution - even if globalisation undermines the wage share. We find strong evidence against the Stolper-Samuelson Theorem for Mexico during the same time period. Moreover, private debt is of no statistical and economic importance to Mexico's wage share. Just to contrast with Chile, mean private 
indebtedness for the period under consideration is $65 \%$ and $11 \%$ of GDP in Chile and Mexico respectively. Interestingly, Mexico's relatively poor financial intermediation has been problematised (Herman and Klemm 2017) but we provide robust evidence that it has been good for the functional income distribution and social stability. This insight suggests that there may be important distributional effects that are ignored in the finance-growth nexus literature (Levine 1997). Based on statistical evidence and our historical analytical narrative for Mexico, this article contends that public consumption is a foundational factor for why wage shares remain stable in that country. This is a remarkable achievement given the extensive deunionisation of labour, loss of public sector employment and wage competition due to openness etc., since the 1980s and 1990s reforms.

Several points are important to note. First, the Chilean case proves just as socially disastrous as the socialist experiments in the newly independent states post World War II that nationalised the 'commanding heights' of their economies. Second, with growing global concern over income inequality and increasing threats to national welfare programs, the Chilean experience of falling wage shares and recent street protests should serve as teachable moments to all newly elected right-wing governments, e.g. far-right leaders in Bolivia and other parts of Europe. Third, efficiency arguments are no longer adequate to justify privatisation or the absence of a public option - Chileans storm the streets of Santiago to bring to the fore concerns over distribution. Fourth, financial deepening as measured by credit to the private sector (private debt) may have ambiguous growth effects due to the distributional channel. In other words, private indebtedness can increase inequality; undermine the sustainability of household-debt and prevailing social contracts.

As compared to Chile, the Mexican case tells an optimistic story - that the negative distributional effects of globalisation are not destiny. Moreover, it shows that a developing economy's public investment and consumption are sufficient to stabilise income distribution and maintain basic social consensus. But why do the Mexican authorities differ from those in Chile? At first glance, these authorities are similar to the extent that IMF supported reforms of privatisation, deregulation and openness etc., were undertaken during the same period. Still, Mexican authorities were not merely ideologues, notwithstanding intense ideological confrontations between state institutions. A healthy dose of pragmatism and the government's desire to court public opinion led to fiscal policy that arrested the adverse effects of IMF supported reforms and wage competition through globalisation. Of course, during the period of Pinochet's dictatorship, public opinion is of no consequence, so that the government can impose austerity by decree. Our historical analysis shows that since 1990 in democratic Chile, a powerful private sector class trumps the ballot to ensure that the Chilean experiment continues. The general thrust of this study confirms that neoliberal economic policies do increase functional income inequality but our case studies also show that the implementation of 
neoliberalism is a path-dependent process (Peck and Tickell 2002) with ambiguous distributional outcomes.

The remainder of the article is organised as follows. Section 2 presents the historical analytical narratives for Chile and Mexico and section 3 presents a summary of the empirical literature. In section 4 and 5 we outline our empirical strategy and results respectively and section 6 provides a short discussion. Finally, we conclude in section 7.

\section{Spatialities of Neoliberalism in Chile and Mexico}

Chile enjoyed a substantial welfare state between 1932-1973 until the overthrow of the democratically elected socialist president, Salvador Allende (Kurtz 2002). The military dictatorship was led by General Pinochet, who was counselled by a team of economists educated at the University of Chicago - the so-called 'Chicago Boys'. Their economic agenda was to establish a society based on supplyside, pro-capital principles, where the pursuit of private enterprise improves societal welfare through trickle-down effects. To this end, the Pinochet regime banned unions, suspended labour laws and prohibited strikes (Davis-Hamel 2012). The economic rationale is based on the idea that unions and other labour market institutions lead to excessive wage growth and unemployment. Moreover, as Davis-Hamel notes, the regime reduced social spending and privatised education, electricity and water supply, health care, social security, telecommunications and banking. Further, the Chicago Boys liberalised trade and permitted the free flow of capital. Also, the private properties that were nationalised during the socialist experiment were returned to their owners. Crucially, these reforms were enshrined in Pinochet's 1980 constitutional reform so that the de facto implementations were given de jure legitimacy.

Predictably, these reforms led to fiscal surpluses, massive capital inflows and rapid growth in private investment that produced the so-called economic miracle - an $8 \%$ annual growth rate between 1977-1981 (Davis-Hamel 2012). At the end of this period, 50\% of domestic credit was denominated in foreign currency and Chile's external indebtedness led to a collapse of capital inflow (Meller 1991). The Chicago Boys were dogmatic monetarists and relied on market forces for adjustment. They contend that the money supply contracts due to insufficient capital inflows, which raises the domestic rate of interest and re-encourages capital inflow to adjust the external account. As a consequence, the rate of interest increased to $45 \%$ and led to a contraction in domestic expenditure by $20 \%$. According to Meller, these effects led to bankruptcies and an unemployment rate of 25\%. By 1982, Chile had devalued its currency twice - by $18 \%$ on June $14^{\text {th }}$ and $40 \%$ on September $29^{\text {th }}$. These devaluations immediately increased the extent of external indebtedness and led to new rounds of bankruptcies. To 
stabilise the financial system, the Chicago Boys were forced to undertake a massive public sector bailout of private banks.

In 1983, the Pinochet regime and the IMF agreed to cut public current and capital expenditure and the public sector's real wage bill. By 1983, the unemployment rate was in excess of $30 \%$. Between 1985-1987, the IMF implemented its Extended Fund Facility that focused on further devaluations to provide an export stimulus to the Chilean economy. This was primarily achieved by cutting real wages and the elimination of wage indexation (Meller 1991).

We argue that entrenched fiscal surpluses, significant devaluations and the removal of labour market institutions etc., - or extreme neoliberalism more generally - can partly explain the dramatic decline in the Chilean wage share since 1980 (see Figure 1). However, democracy returned to Chile in 1990 but as illustrated in Figure 1, the Chilean economy continued to experience a steady decline in its wage share. What are the potential explanatory factors for the dynamics of functional income inequality in democratic Chile? Since 1990, coalition governments governed the country with extensive intra-elite contestations regarding the role of the state. The orthodox faction won the day and controlled the Ministry of Finance, which rejected interventionist state policies but kept in place free trade, fiscal conservatism and fundamentalist neoliberal economic policies (Bril-Mascarenhas and Madariaga 2019, Madariaga 2017, Weyland 1999).

The literature advances several reasons why Pinochet's neoliberalism persisted. First, his neoliberal project created a strong business constituency, particularly the export-oriented sectors that profited under an official policy of small government (Kurtz 1999). This constituency serves as an important source of 'check' on government policy. For example, Bril-Mascarenhas and Madariaga (2019) argue that the private sector threatens state officials with disinvestment should the role and scope of government expand. Moreover, according to Bril-Mascarenhas and Madariaga, captains of industry were graduates of the University of Chicago, schooled in monetarism and therefore, genuine sceptics of government. Campero (1993) and Frieden (1991) argue that the socialist experiment infused an anti-statist value system in the private sector that persists in democratic Chile. Given the enormous de facto political power of the business community, the main economic objective of successive coalition governments is to build the trust of the private sector by maintaining the status-quo (Kaplan 2013). Notwithstanding the general thrust to maintain neoliberal economic policies, the centre-left coalitions did manage to implement a minimalist quasi-universal public benefits program (Kurtz 2002) but as Figure 1 demonstrates, Chile's welfare programs were of no consequence to its functional income distribution. 
Figure 1: Wage Shares, 1980-2011

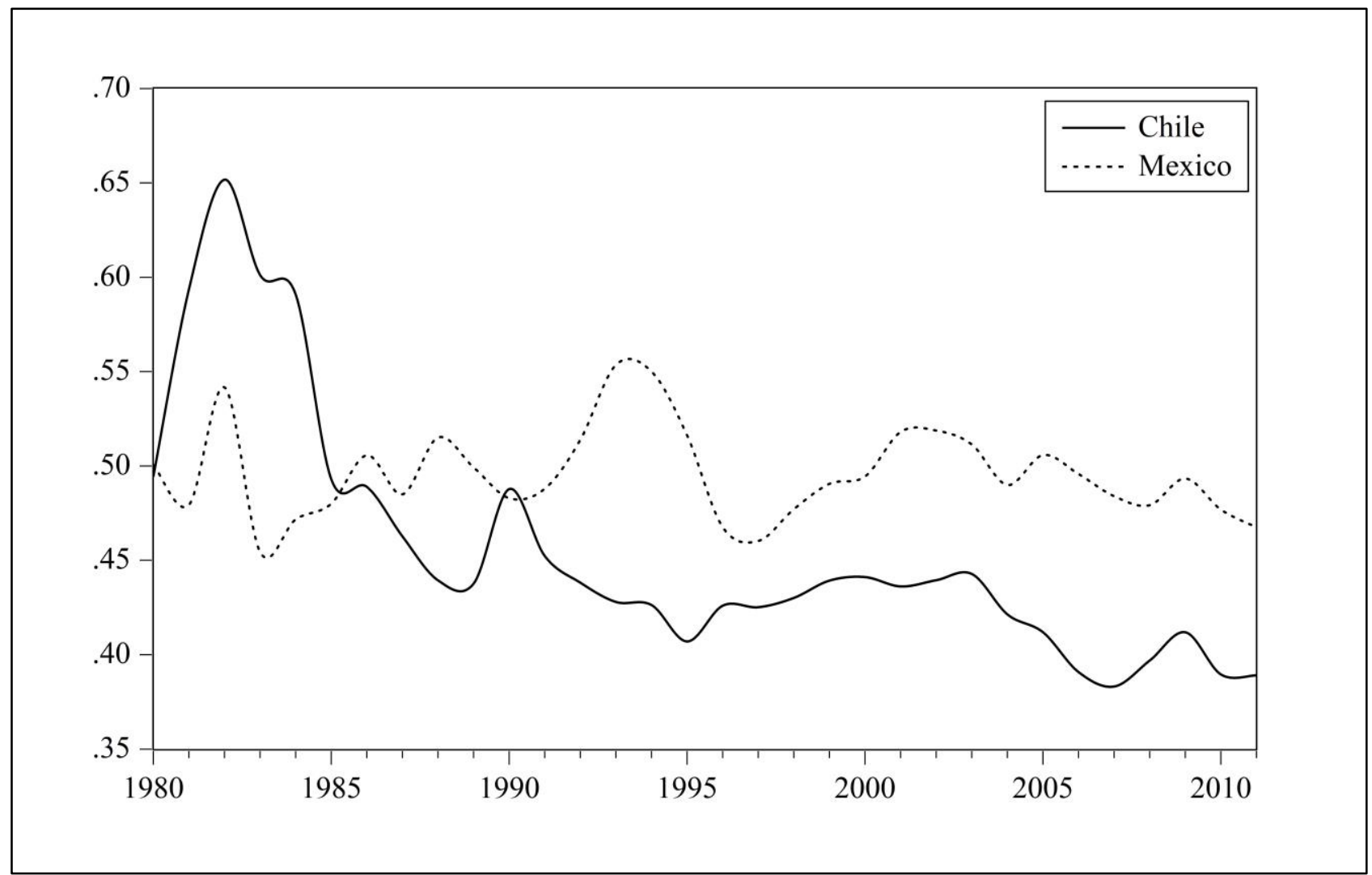

Notes: The wage share is the sum of unskilled (agricultural and minimum wage urban workers), semi-skilled (manual manufacturing workers), and skilled (bank tellers and clerks) wages as a share of GDP (Source: Astorga (2017))

Regarding Mexico, after the revolution against the Porfirio Diaz dictatorship, President Cardenas united his country under a strong nationalist government with a social vision, 1934-1940. His presidency marked the emergence of party politics as a means to settle ideological disputes. This led to the integration of politicians with different political views - e.g. socialism, liberalism and conservatism - into state institutions (Ortiz 2019). One prominent institution was the central bank under the leadership of Luis Monteds de Oca, who targeted inflation with tight monetary control and refused to fund fiscal deficits. Upon Oca's invitation, Ludwig von Mises was invited to give talks in 1942 and 1946 and this led to the formation of Mexico's early neoliberal stream of thought - supported by bankers, businessmen and young scholars. Other prominent scholars that advocated libertarian ideas, such as Hayek, were also invited to give lectures and seminars. The central bank provided numerous scholarships to study economics at the Universities of Chicago, MIT, Yale etc., and graduates found employment in the central bank, ministries for the economy, industry and trade (Ortiz 2019). Ortiz argues that the National University of Mexico also funded studies in Cambridge, Poland and Paris that supported state planning and Keynesian economics. Between 1954-1970, Mexico had a 
welfare state, encouraged FDI, enforced protective trade tariffs and nationalised key industries: oil extraction, electricity, transportation etc.

The discovery of oil in the late 1970s led to increased foreign borrowing that supported public consumption and investment (Silva Herzog 2007). The government called the growth period of 19711979 'Shared Development' and faced increasing private sector opposition to rising taxes and nationalisation (Morton 2003). During this period, the government invested heavily in the petrochemical industry, infrastructure and subsidised domestic consumption to maintain real wages (Ortiz 2019). The oil boom increased both private and public external indebtedness and a decline in the price of oil and rising interest rates led creditors to question Mexico's ability to repay. This sharpened the ideological battle within government and led to a confrontation between the Bank of Mexico and the Heads of Budget and Programming.

The Mexican debt crisis in the 1980s strengthened the alliance between the private sector and the Bank of Mexico and the first IMF agreement in 1983 further deepened the ideological division within the Institutional Revolutionary Party (PRI) and state institutions (Ortiz 2019). In 1988, Mexico had devalued its currency and extensive reforms followed in the second IMF agreement in the 1990s. The government had introduced a value-added tax, agreed to cut public indebtedness by cutting public employment, increased provision of public goods, liberalised trade, floated the foreign exchange rate and imposed a public sector wage freeze (Ortiz 2019). Additional reforms included the privatisation of state-owned companies; lower corporation taxes, opening up of capital account and de-regulation of financial activities (Laurell 2015). Crucially, privatisation weakened the power of labour unions and new export-oriented industries hired non-unionised labour (Gonzalez and McKinley 1997).

Unlike the case of Chile, Mexico's technocrats were not dogmatic about these policies; they were keen to increase public spending to mitigate the adverse social effects (Kurtz 2002, Morton 2003). One instance of this pragmatism is the National Solidarity Programme (PRONASOL) between 1989-1994. This was largely a poverty alleviation strategy that involved the citizenry in both design and implementation. It included public funds for community development projects and applied the principle of 'Tequio', a form of labour organisation where members contribute labour time and resources (Ortiz 2019 and Morton 2003). Laurell (2015) highlights additional components of Mexico's social policy: conditional cash transfers, robust public education and health care. A similar programme was implemented between 1995-2001 known as PROGRESA.

Morton (2003) indicates that PRONASOL is not merely the outcome of pragmatism but also the government's attempt to regain political legitimacy after the Tlatelolco massacre, where the armed 
forces killed civilians during a large demonstration. Nonetheless, Mexico's post-1980 growth model was based on a variegated or hybrid neoliberal foundation, since it did not involve a retreat of the state but a reorganisation of state institutions. The latter is based on the assembly of light manufacturing, low wages for the export industry and large migrant and remittance flows. This brief analytical narrative suggests that Mexico's relatively stable wage share can be potentially explained by the hybrid nature of its growth model, i.e. strong public consumption/investment that compensates for the adverse effects of neoliberal trade policies.

\section{Has Neoliberalism caused rising income inequality?}

A burgeoning body of literature within social sciences has scrutinised how the neoliberal policy agenda has weakened industrial relations and increased income inequality. Overall, the literature identifies four core determinants of growing functional income inequality: the degree of labour market regulation, welfare expenditures, trade globalisation and financialisation.

Several micro, macro and meso-level empirical studies have demonstrated that the deregulation of the labour market, declining labour militancy and welfare state retrenchment have increased the cost of job loss, engendered higher functional income inequality and wage dispersion. Prominent micro and meso-level empirical examples that support these arguments are Cowling and Molho (1982) and Leslie and Pu (1996) for Britain, Dell'Aringa and Pagani (2007) for Italy, Belgium, and Spain, and Devincieti et al. (2019) for Italy. Fichtenbaum (2009) present macro-level evidence for the USA and Kristal (2010), Hancke (2012), Pontusson (2013) and Bengtsson (2014) provide macro panel analyses for other advanced economies.

Beyond labour market institutions and welfare state retrenchment, trade and production globalisation are important determinants of functional income inequality. Trade openness has made export-oriented firms cut overhead costs, e.g. wages to maintain price competitiveness. Additionally, the globalisation of value chains (Gereffi et al. 2005) allows multinational companies to relocate to low-wage economies, which undermines labour's bargaining power in both advanced and developing countries (Rodrik 1997).

A number of studies have empirically identified that these globalisation processes have made labour more vulnerable to wage squeezes. Grant and Wallace (1994) and Brady and Wallace (2000) report that Foreign Direct Investment (FDI) has led to declining labour militancy and higher income inequality between 1970 to the late 1990s using a sample of 48 US states. Boulhol et al. (2011) employ firm-level data from the UK's manufacturing sector and demonstrate that labour's bargaining power and the mark-ups of small firms have declined due to import penetration between 1988-2003. 
Böckerman and Maliranta (2012) used longitudinal plant-level data for the period 1976-2007 and show that rising export share and foreign ownership have triggered intra-industry restructuring in Finland, which forced high labour share plants to exit their industries and led to declining labour shares.

Macro-level panel data studies like those of Harrison (2002), Jayadev (2007), ILO (2008), IMF (2017) and Stockhammer (2017), provide further empirical evidence that different dimensions of globalisation have contributed to the decline of wage shares since 1970. Their proxies include trade openness, capital account openness, FDI and the share of foreign assets and liabilities. Flaherty and Riain (2019) report time series macro-level evidence that trade openness and FDI decreased Ireland's wage share but did not affect functional income distribution in Denmark between 1960 and 2012. They claim that these discrepancies stress the key role of domestic institutions and politics, which underscores the importance of country-level studies.

Only a handful of studies focus on the distributional effects of globalisation in developing countries and these are largely panel-based analyses that do not allow for an in-depth understanding of important institutional differences. One exception is Onaran (2009), who shows that globalisation has reduced the manufacturing labour shares of Korea, Mexico and Turkey between the late 1970s and 2003. Globalisation indicators like the FDI, imports and exports value-added are particularly influential for Mexico and Turkey, while nominal exchange rate depreciations have a negative effect in all countries. According to Onaran, these findings highlight that the distributional effects of trade depend on domestic industrial policy strategy and thus, institutional innovation. The governments of Turkey and Mexico followed an orthodox wage suppression policy to shift the growth model towards an exportoriented strategy since the 1980s. This is consistent with the argument that trade globalisation encourages labour-saving technical change and empowers capital. In contrast, Korea's export strategy was based on investment in skill- and technology-intensive goods rather than wage suppression, hence the insignificant impact of trade openness on Korea's wage share. However, Korea's integration with the world economy exposed it to financial and exchange rate crises, which explains why the nominal exchange rate is an important driver of its wage share. The second exception is Guschanski and Onaran (2017), these scholars find that offshoring towards emerging economies and financial integration have reduced the labour share in Korea, Mexico, Turkey, Brazil, China, Indonesia, and India, for the period 1995-2009 using industry-level panel datasets. These results confirm that trade globalisation can be particularly harmful to the working class in developing countries. Guschanski and Onaran also find negligible effects of labour-saving technical change as proxied by capital intensity. Finally, Ibarra and Ross (2019) examine Mexico over the period 1990-2012 using sectoral data and claim that the relative decline of the labour shares in the formal sectors is due to lagging productivity in the informal nontradable sector and the reduction of the US manufacturing labour share. 
Another strand of the literature focuses on the financialisation of non-financial sectors. Financialisation has been highlighted as a driver of inequality through three distinct channels: the financialisation of households; the financialisation of non-financial firms via corporate indebtedness and shareholder value orientation; and the rise in the financial profits of non-financial sectors. Froud et al. (2002) and Langley (2007) argue that the financialisation of households through the accumulation of debt has induced a loss aversion behaviour by workers on the fear of defaulting on their debt. This leads them to accept stagnant or even lower wages and avoid union participation to demonstrate 'good' behaviour to their employers. Darcillon (2015), Kollmeyer and Peters (2019) and Meyer (2019) show that financialisation has played a role in the decline in employment protection and unionisation in advanced countries during neoliberalism. Wood (2017), Guschanski and Onaran (2018), and Köhler et al. (2019) demonstrate that household indebtedness has caused declines in the labour share since the early 1970s, especially in advanced liberal market economies with indebted low-income households.

Neoliberal financialisation also includes non-financial firms and over the last four decades, firms borrow for at least two reasons: 1 . first, to invest in capital accumulation and 2. second, to buy back their shares. The latter motive has been identified as a common practice due to the separation between the management and the owners of contemporary firms. Shareholders' income ultimately depends on dividend payments, i.e. on increases in the value of a company's stocks. Thus, shareholders press managers to become short-termists and boost share prices to maximise their income. ${ }^{1}$ As noted by Lazonick and O'Sullivan (2000), managers undertake corporate debt and engage in share buybacks to boost share prices, which worsens the financial position of the firm. In order to improve the latter, managers endeavour to cut costs/wages by downsizing (Froud et al. 2000, Thompson 2003). This process has triggered a decline in real long-term investment (Stockhammer 2004), worsened industrial relations (Gospel and Pendleton 2003, Palpacuer et al. 2011, Appelbaum et al. 2013) and increased functional income inequality in advanced economies (Dünhaupt 2017, Köhler et al. 2019).

An important dimension of financialisation is the rise in financial profits of non-financial firms (Krippner 2005, Stockhammer 2013; Lapavitsas and Mendieta-Muñoz 2019). The liberalisation of financial activities allowed non-financial firms to become more flexible and expand their activities to financial investments. Lin and Tomaskovic-Devey (2013) claim that this shift towards financial profits makes profitability less dependent on labour and value creation. Using industry-level data for the USA, they demonstrate that rising financial incomes decreased the labour share between 1970 and 2008 . Similarly, Alvarez (2015) reports that financial profits and interest payments reduced the labour share of 6,980 French non-financial corporations over the period 2004-2013.

${ }^{1}$ E.g., for the case study of Apple see Lazonick et al. (2013) 
In sum, the existing empirical literature offers compelling evidence that labour market deregulation, welfare state retrenchment, globalisation and financialisation have substantially contributed to the reduction of labour shares since the early 1980s. The few exceptions that take into account developing economies are based almost exclusively on panel data analysis - pooling countries with significant institutional, political and cultural differences - or use micro and meso-level datasets that do not extend prior to the mid-1990s. This article is motivated by these shortcomings and aims to illustrate how the political economy dynamics of inequality in Chile and Mexico might be similar or different from advanced country experiences.

\section{Empirical design and data sources}

We estimate our single-equation model using the unrestricted Error-Correction Model (UECM), pioneered by Sargan (1964) and Davidson et al. (1978). This econometric specification accounts for the serial correlation issues of the standard OLS model by including both the short-run (firstdifferenced) and the long-run (level) effects of the independent variables. ${ }^{2}$ The two necessary conditions for the implementation of this model is that all variables must be either $\mathrm{I}(0)$ or $\mathrm{I}(1)$ and that there must be a cointegrating relationship among the dependent and the independent variables. In our case, both conditions are satisfied. ${ }^{3}$ The long-run coefficients are in lagged form in order to prevent simultaneity issues. Our analysis relies on annual macroeconomic data that covers the 1980-2011 period. To test a variety of political economy explanations for the drivers of income inequality, we form a synthetic, exploratory baseline specification that includes proxies for welfare state retrenchment, trade globalisation, and financialisation:

$$
\begin{gathered}
\Delta(\text { Wage Share })_{t}=\beta_{0}+\beta_{1}(\text { Wage Share })_{t-1}+\beta_{2}{\text { (Government Consumption })_{t-1}}_{+\beta_{3}(\text { Trade Openness })_{t-1}+\beta_{4}(\text { Terms of Trade })_{t-1}+\beta_{5}(\text { Private Debt })_{t-1}} \\
+\beta_{6}(\text { Stocks Traded })_{t-1}+\sum_{n=0}^{N} \gamma_{n} \Delta z+\varepsilon_{t}
\end{gathered}
$$

where the terms $\beta_{0}$ and $\varepsilon_{t}$ are the constant and the error terms respectively, while $z$ is a vector that includes the short-run (first-differenced) coefficients. The growth rate is included as a short-run control

\footnotetext{
2 The UECM model is widely used in this literature, e.g., see Kristal (2010), Bengtsson (2014a), and Flaherty and Riain (2019). Our interest is targeted on the long-run coefficients, i.e., the long-term structural processes, rather than on the shortterm coefficients, i.e., the reactions to temporary shocks.

${ }^{3}$ As reported in the appendix, all variables are either $\mathrm{I}(0)$ or $\mathrm{I}(1)$. Regarding cointegration, the residuals of the stationary regression between the wage share and the explanatory variables are stationary, thus, a long-run relationship exists.
} 
variable to account for the cyclicality of the wage share. Adopting the most common UECM specification, the long-run coefficients are in lagged form to prevent simultaneity issues.

Government Consumption (final expenditure excluding military spending as a share of GDP) is included as a proxy for welfare spending and public investment, which decreases the cost of job loss, thus, empowers labour and increases the wage share. Trade Openness (sum of exports and imports as a share of GDP) is a commonly used proxy for the extent of openness: capital mobility and the degree of integration into world trade or globalisation. Terms of Trade (Net barter terms of trade index, i.e. the export unit value index over the import unit value index) captures the reaction of employers to changes in international prices. There are two competing propositions: (a) if higher export prices are due to rising wages, export-oriented firms will squeeze wages to maintain target profitability or pricecompetitiveness and (b) if higher export prices are on account of global demand, wages may rise with terms of trade. Private Debt (domestic credit provided by the financial sector as a share of GDP) can undermine the wage share through two channels: (a) household debt increases the costs of job loss and thus, reduces labour's bargaining power and (b) non-financial corporate debt deteriorates firms' balance sheet and wage squeezes/freezes can be relied upon to improve their financial position. ${ }^{4}$ Stocks Traded (total volume as a share of GDP) captures the new business philosophy of shareholder value maximisation, which is associated with firm downsizing, cost-cutting and share buybacks rather than re-investment, ergo, a lower wage share.

We estimate six additional specifications including one additional control variable in each to evaluate the robustness of the main results. Capital Intensity is included as a proxy for how technological progress affects functional income distribution. Given a high elasticity of substitution between workers and machinery (Hicks 1932), technological progress reduces labour demand and real wages. However, empirical estimates suggest that the elasticity of substitution is significantly less than unity, which implies that technical change need not undermine the wage share (Rowthorn 1995). The Manufacturing value-added Share of GDP is incorporated as a control variable to capture the effects of structural changes on income inequality. A rising manufacturing share is expected to increase the wage share through several channels: technology/manufacturing-intensive economic activities have longer job ladders, a wider range of occupational choice, flatter hierarchy of occupational structure, wider diffusion of skills and knowledge, stronger collective bargaining and higher income elasticity in export markets, thus, lower inequality (Hartmann et al. 2016; Constantine 2017, Constantine and Khemraj 2019). Subsequently, we add Strike Activity (total number of strikes and lockouts) as an

\footnotetext{
${ }^{4}$ We use the total private debt-to-GDP ratio instead of separate series for household and corporate debt, since such disaggregated data do not extend prior to 1995 for either country.
} 
indicator for the degree of labour militancy - due to lack of unionisation data - which is expected to exhibit a positive effect on the wage share. Public Debt (share of GDP) is included as a proxy indicator for the power of bondholders. Since government pay interest payments to bondholders, the latter may exercise undue influence over fiscal policy to raise taxes on wage income (Streeck 2014, Hager 2015). The KOF Index is incorporated as a wider measure of economic, social, and political globalisation. In short, the index reflects a comprehensive shift in bargaining power in favour of firms and ergo, we expect a lowering of the wage share in the presence of hyper-globalisation. ${ }^{5}$ To control for the political regime we include the Polity 2 Score, which ranges from -10 (hereditary monarchy) to +10 (consolidated democracy). In a more democratic economy workers and owners of firms are equally represented, which implies that too low wages can be democratically adjusted.

As further robustness checks, we estimate four additional specifications. First, we include FDI Inflows (Net share of GDP) as an alternative proxy for capital mobility with ambiguous effects on the wage share, depending on the domestic strategy of attracting FDI. If firms are attracted by low wages, then the relocation threat remains high and local workers will accept low wages. Second, we add the Nominal Exchange Rate (official exchange rate; LCU per US\$, period average) as a control variable, where nominal depreciations/devaluations reduce the wage share. Natural Resources Rents (share of GDP) can also affect the wage share, especially in resource-rich developing economies like Chile and Mexico. When natural resources rents are privately and publicly owned, firm-level costs of production can increase and decrease respectively. As costs rise, international price competitiveness is undermined and wages are squeezed (Mazzucato et al. 2020). Finally, we introduce one countryspecific dummy variable for each country. For Mexico, the time dummy variable indicates the 1994 implementation of NAFTA, which is anticipated to decrease the labour share due to the higher relocation/globalisation threat. For Chile, the time dummy variable represents the 1992 copper privatisation Codelco Law. This law indicates the fall of the state-controlled copper sector under the Pinochet dictatorship. Depending on the wage share under the state-controlled firm, privatisation can increase or decrease the wage share.

Regarding data sources, the wage share series is taken from Astorga (2017), Strike Activity data is sourced from ILOSTAT, Capital Intensity comes from Bergeaud et al. (2016), the KOF index comes from Gygli et al. (2019), the Public Debt source is the IMF and the Polity2 Score comes from the Center for Systemic Peace. All other data is sourced from the World Bank database. Our investigation starts in 1980 because of the stylised fact in the political economy literature that neoliberalism begins

\footnotetext{
${ }^{5}$ To avoid multicollinearity biases the Terms of Trade index is replaced with the KOF Index, which includes trade-related indices.
} 
in earnest in the late 1970s. Our end date is determined by data availability. To preserve consistency and avoid introducing biases, we do not combine Astorga's (2017) series - the only annual macro series that extend to 1980 - with other more recent data that proxy the wage share. Descriptive statistics can be found in the appendix.

\section{Econometric results}

\subsection{Chile, 1980-2011}

In specification (1) we find that both Government Consumption and Private Debt have the expected positive and negative signs respectively and are statistically significant at the one percent level. Stocks Traded has the expected negative sign but is not statistically significant. In contrast, Trade Openness and Terms of Trade exhibit unexpectedly positive effects and are statistically significant at the five percent level. However, as compared to the magnitude of the coefficients for Government Consumption and Private Debt these are substantially smaller.

In specifications (2) and (3), Capital Intensity and the Manufacturing Share do not produce results that deviate from the baseline findings. In specification (3), the effect of the Manufacturing Share on the wage share is positive and statistically significant at the five percent level. In specification (4), the addition of Strike Activity does not change the baseline results. The control variable itself exhibits the expected positive effects on the labour share but is statistically insignificant. Specification (5) controls for Public Debt but does not change the baseline results in terms of signs, statistical significance and magnitude. When we replace Terms of Trade with the KOF Index in specification (6) only minor changes are observed. Government Consumption, Private Debt and Trade Openness keep their expected signs and remain statistically significant. The KOF Index itself has the expected negative sign but the coefficient is statistically insignificant, while Stocks Traded becomes weakly positive and borderline statistically significant. Finally, in specification (7), incorporating the Polity2 Score does not alter the baseline results. The control variable itself exhibits the expected positive sign. 
Table 1: Chile, 1980-2011 - Econometric results

\begin{tabular}{|c|c|c|c|c|c|c|c|}
\hline & $(1)$ & $(2)$ & (3) & (4) & $(5)$ & (6) & $(7)$ \\
\hline \multicolumn{8}{|l|}{ Long-run coefficients } \\
\hline Wage Share $_{t-1}$ & $-1.273 * * *$ & $-1.530 * * *$ & $-1.675^{* * *}$ & $-1.272 * *$ & $-1.309 * *$ & $-0.703 *$ & $-1.330 * * *$ \\
\hline Government Consumption $_{t-1}$ & $1.702 * * *$ & $1.914 * * *$ & $1.884 * * *$ & $1.761 * * *$ & $1.675^{* *}$ & $2.094 * * *$ & $1.814 * * *$ \\
\hline Trade Openness ${ }_{t-1}$ & $1.027 * *$ & $1.220 * * *$ & $1.274 * * *$ & $1.106^{*}$ & $1.089 *$ & $1.194 * *$ & $0.981 * *$ \\
\hline Terms of Trade ${ }_{t-1}$ & $0.758 * *$ & $0.699 * *$ & $0.905 * * *$ & $0.788 * *$ & $0.966 * * *$ & & $1.122 * * *$ \\
\hline Private Debt $t_{t-1}$ & $-1.745^{* * *}$ & $-1.400 * *$ & $-1.753 * * *$ & $-1.809 * *$ & $-1.930 * * *$ & $-1.726 * *$ & $-1.853 * * *$ \\
\hline Stocks Traded $_{t-1}$ & -0.370 & -0.207 & -0.193 & -0.392 & -0.510 & $0.690 *$ & -0.632 \\
\hline Capital Intensity $_{t-1}$ & & -0.655 & & & & & \\
\hline Manufacturing Share ${ }_{t-1}$ & & & $0.667 * *$ & & & & \\
\hline Strike Activity $_{t-1}$ & & & & 0.029 & & & \\
\hline Public Debt $_{t-1}$ & & & & & -0.372 & & \\
\hline$K O F$ Index $_{t-1}$ & & & & & & -0.538 & \\
\hline Polity2 Score $_{t-1}$ & & & & & & & 0.511 \\
\hline$R^{2}$ & 0.88 & 0.90 & 0.91 & 0.88 & 0.90 & 0.85 & 0.89 \\
\hline$B G$ & 0.77 & 0.72 & 0.82 & 0.75 & 0.67 & 0.87 & 0.88 \\
\hline Harvey & 0.39 & 0.26 & 0.39 & 0.44 & 0.33 & 0.03 & 0.18 \\
\hline Obs & 31 & 31 & 31 & 31 & 31 & 31 & 31 \\
\hline \multicolumn{8}{|c|}{$\begin{array}{l}\text { Notes: Statistical significance at } 10 \%, 5 \% \text {, and } 1 \% \text { level is denoted by } *, * *, \text { and } * * * \text {, respectively. The dependent variable is the Wage } \\
\text { Share in first differences. The coefficients reported are standardised by multiplying the obtained coefficient with the ratio of the standard } \\
\text { deviation of the explanatory variable over the standard deviation of the dependent variable. Values for specification tests are p-values. } \\
\text { BG (Breusch-Godfrey) test at first lag only. Constant terms and short-run (first-differenced) coefficients are included in the estimations, } \\
\text { but not reported. }\end{array}$} \\
\hline
\end{tabular}

Our core findings demonstrate that government consumption and private debt increase and decrease Chile's wage share respectively and these results are robust to various controls. The magnitudes of these coefficients are striking and underline them as primary drivers of the steep decline of the Chilean labour share since 1980. More concretely, steady decreases in government consumption and the financialisation of the non-financial sector are important explanations for why the Chilean wage share has fallen. The paper also finds that Trade Openness and Terms of Trade increase the wage share, though these results are substantially weaker in magnitude. Unlike the robust result in advanced economies that globalisation lowers the wage share, Chile's exports of copper and other natural resources that have benefitted from Latin America's commodity boom is a boon for its wage share. We find weak evidence that the commodity boom might have engendered a premature deindustrialisation that lowers the Chilean wage share. Further evidence for the robustness of our baseline results is provided in Table A4 of the appendix. 


\subsection{Mexico, 1980-2011}

In specification (1), Government Consumption, Trade Openness, Terms of Trade and Stocks Traded have their expected signs and are statistically significant, with the exception of the latter. Specification (2) controls for Capital Intensity but does not change the baseline results. The control variable itself has the expected negative sign and is statistically significant at the one percent level. Regarding specification (3), incorporating the Manufacturing Share in the baseline specification does not affect the main findings in terms of signs and statistical significance. Similarly, adding Strike Activity in specification (4) also does not trigger major changes. Both Government Consumption and Trade Openness remain statistical determinants of Mexico's wage share. Notably, the effect of Strike Activity is positive but the coefficient is statistically insignificant. The addition of Public Debt in specification (5) leads to almost identical results, with the control variable being negative and non-significant. In specification (6), Government Consumption and Trade Openness become statistically insignificant when the KOF Index replaces the Terms of Trade. However, both variables keep their expected signs and their magnitudes remain similar to the baseline findings. Interestingly, the impact of Stocks Traded becomes positive and borderline statistically significant. Finally, in specification (7), where we control for the Polity2 Score, the findings remain similar to the baseline results in terms of signs, magnitudes and statistical significance.

Table 2: Mexico, 1980-2011 - Econometric results

\begin{tabular}{|c|c|c|c|c|c|c|c|}
\hline & $(1)$ & $(2)$ & (3) & (4) & (5) & (6) & (7) \\
\hline \multicolumn{8}{|l|}{ Long-run coefficients } \\
\hline Wage Share ${ }_{t-1}$ & $-0.411 *$ & $-0.602 * *$ & -0.355 & $-0.434 * *$ & $-0.605 * *$ & $-0.648 * * *$ & $-0.601 *$ \\
\hline Government Consumption $_{t-1}$ & $0.620 * *$ & $0.876 * * *$ & $0.960 * *$ & $0.363^{*}$ & $0.647 * *$ & 0.529 & $0.608 * *$ \\
\hline Trade Openness ${ }_{t-1}$ & $-0.812 * *$ & $-1.268 * * *$ & $-0.707 *$ & $-0.586 * *$ & $-1.131 * *$ & -0.786 & $-1.330 *$ \\
\hline Terms of Trade ${ }_{t-1}$ & $-1.133 * *$ & $-1.317 * * *$ & $-1.176^{* * *}$ & -0.563 & $-1.143 * *$ & & $-1.004 * *$ \\
\hline Private Debt $t_{t-1}$ & 0.127 & -0.209 & 0.353 & -0.095 & -0.373 & -0.530 & 0.069 \\
\hline Stocks Traded ${ }_{t-1}$ & -0.165 & -0.119 & -0.372 & 0.098 & 0.173 & $0.837 *$ & -0.080 \\
\hline Capital Intensity $_{t-1}$ & & $-0.495 * *$ & & & & & \\
\hline 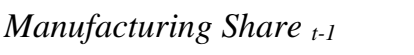 & & & 0.486 & & & & \\
\hline Strike Activity $_{t-1}$ & & & & 0.209 & & & \\
\hline Public Debt $t_{t-1}$ & & & & & -0.489 & & \\
\hline$K O F$ Index $_{t-1}$ & & & & & & -0.042 & \\
\hline Polity2 Score $_{t-1}$ & & & & & & & 0.549 \\
\hline$R^{2}$ & 0.71 & 0.79 & 0.79 & 0.86 & 0.76 & 0.61 & 0.74 \\
\hline$B G$ & 0.12 & 0.12 & 0.14 & 0.07 & 0.15 & 0.34 & 0.10 \\
\hline Harvey & 0.54 & 0.33 & 0.48 & 0.16 & 0.59 & 0.42 & 0.47 \\
\hline Obs & 31 & 31 & 31 & 31 & 31 & 31 & 31 \\
\hline
\end{tabular}


the standard deviation of the explanatory variable over the standard deviation of the dependent variable. Values for specification tests are p-values. BG (Breusch-Godfrey) test at first lag only. Constant terms and short-run (first-differenced) coefficients are included in the estimations, but not reported.

Overall, our empirical findings demonstrate that the key drivers of the Mexican labour share are the relative expansion in public consumption - especially after 1995 - and its increasing exposure to globalisation. The evidence suggests that government consumption compensates for the negative wage share effects of opening the Mexican economy. This can explain why the wage share remains stable between 1980 and 2011 as compared to Chile. We also find evidence of capital-labour substitution as proxied by Capital Intensity, which indicates that firms were able to take advantage of labour-saving technical progress. The impact of financialisation on the functional income distribution is negligible in the Mexican case. Additional robustness checks are reported in Table A4 of the appendix.

\section{Discussion}

Why have wage shares fallen in Chile but remain stable in Mexico? This work presents robust evidence that Chile is more financialised - significantly higher debt levels for firms and households that undermine wage demands and encourage firms to cut wage costs. Also, Chile's history with Chicago trained economists and corresponding policy of small governments and private provision of social services (Clark 2017), have led to a significant and persistent decline in its wage share. Chile's neoliberal experimentation has come home to roost with a vengeance, given recent protests in that country (McGowan 2019). We present strong evidence that the positive effects of Chile's integration into the world economy - though substantial - were insufficient to compensate for the negative effects of its neoliberal policy regime that forced both firms and households to incur debt. These are striking findings that illustrate the importance of public services in taming distributional conflict and preventing mass social discontent.

In our estimation, the Chilean case is a teachable moment for other developing and advanced countries that might choose to sacrifice their welfare programs at the altar of fiscal responsibility. In the interest of policy, it imperative to recall that Chile is regarded as a shining example of fiscal prudence and sound macroeconomic management (Daban 2011). Therefore, this also illustrates a crisis in macroeconomic theory that dismisses labour market institutions or government welfare as distortionary (Storm and Naastepad 2012) and fails to appreciate how a strong wage share lowers debt, maintains social content and strengthens macro and financial stability (Stockhammer 2015). The Chilean case also contributes to the reprimarisation debate in Latin America (Cooney 2016). The commodity boom in the 2000s has caused many to reassess their pessimism with commodity 
specialisation. Our evidence demonstrates that a natural resource/commodity boom can undermine the industry and the wage share. Much of the literature focuses on industrialisation and economic growth (Constantine 2017) but we find evidence that the distributional effects might be just as important given the political economy effects of social discontent.

The Mexican case presents an example of how integration into the world economy might remain socially acceptable. As compared to Chile, Mexico is more capital intensive in terms of both input and output, which implies that the competitive forces of globalisation engender significant substitution effects. Predictably, this undermines the wage share but the Mexican case demonstrates that globalisation is not destiny. Government consumption has increased in tandem and sufficiently to stabilise its wage share and maintain comparatively better social content. The strong provision of public services can enhance wage bargaining and reduce the propensity for firm-level and household debt. Mexico proves that the forces of globalisation can be managed even when there are strong negative distributional effects from openness.

These comparative results illustrate that the distributional effects of world integration are ambiguous and that policy matters. Both conclusions are contrary to the popular narratives that led to a hyper-globalisation and the homogenisation of policy. In terms of policy, the comparative study makes a strong case for openly discussing the negative distributional effects of globalisation so that an effective compensatory strategy can be democratically devised. In our view, an effective strategy is one that stabilises the wage share. However, the Chilean results show that public services remain important for social content even when globalisation lowers inequality. In other words, higher wage shares do not reduce the utility of government welfare or justify the privatisation of key public services. 
Figure 2: Key Contributions to the Wage Share



Figure 2 illustrates the sharp contrast between Chile and Mexico as it relates to the key contributions to their respective wage shares. The sizable effect of government consumption in Chile captures the enormous reductions in fiscal expenditure in that country and the extensive privatisation of key public services. It is remarkable that the mean Terms of Trade and Openness are similar in both countries but produce different and significant wage share effects. The positive effects in Chile add support to the Stolper-Samuelson Theorem - that the more abundant factor gains from international trade (Stolper and Samuelson 1941) - but this is not borne out in the Mexican case. It follows that free trade does not unambiguously lower inequality in developing countries and that what a country exports might matter for distributional outcomes. For example, as compared to Chile, the larger share of Mexican exports is machinery and complex manufactured goods, which are comparatively more price elastic and ergo, justifies wage restraint or reductions. It is well known that the commodity boom in recent decades has lowered inequality in Latin America and the Chilean case is no exception (SanchezAncochea 2019).

The literature on the finance-growth nexus places much emphasis on the extent of financial intermediation (Levine 1997) but as Figure 2 shows, credit intermediation or private debt can serve as a powerful propeller for functional income inequality. It follows that this highly influential school of thought can sow the seeds of extractive growth processes. Based on this indicator of financial development, Mexico is underperforming and just to fix ideas, private debt as a share of GDP in Chile 
and Mexico are $65 \%$ and $18 \%$ respectively. This is a sharp contrast and a recent IMF study calls for extensive reforms to expand financial deepening in Mexico (Herman and Klemm 2017). Whether the Mexican authorities pursue a policy of financial restraint or the low credit depth is due to an inefficient banking system or the informal sector, Mexico's wage share has benefitted from this lack of financial development. Our finding is hardly supportive of poor credit intermediation, rather, it adds pause to the finance-growth nexus and lay bare the adverse distributional effects.

\section{Conclusions}

This article compares and contrasts the determinants of functional income inequality in Chile and Mexico between 1980-2011. We find robust evidence that certain aspects of neoliberalism have negatively affected the labour shares of both economies. Our comparative perspective provides important empirical and theoretical insights. First, trade globalisation does not necessarily lower the wage share since its effect depends on domestic production structures. In Mexico, globalisation exposed its labour-intensive industries to wage competition, which reduces its wage share. However, Chile's commodity-based export industries and its wage share have benefitted from the so-called China shock. Second, given the existing literature and our results, welfare spending is a positive driver of the wage share in both advanced and emerging countries. Fiscal austerity in Chile led to an increase in function income inequality since 1980, whilst in Mexico, higher government spending counterbalanced the negative effects of globalisation. Third, extensive financialisation does lead to higher income inequality in developing economies like Chile. Fourth, financial deepening is not a prerequisite for growth, and certainly not inclusive growth, as the Mexican case suggests. These comparative results demonstrate the importance of country-level studies as each country's historical evolution and its variegated process of neoliberalisation can tell unique distributional stories. Future work must rely more on historicised country-level analysis to unveil key institutional differences or the varied implementation of neoliberalism in developing countries. 


\section{References}

Alvarez, I. (2015) 'Financialization, non-financial corporations and income inequality: the case of France', Socio-Economic Review 13: 449-75.

Appelbaum, E., Batt, R. and Clark, I. (2013) 'Implications of financial capitalism for employment relations research: evidence from breach of trust and implicit contracts in private equity buyouts', British Journal of Industrial Relations 51(3): 498-518.

Arestis, P. and Phelps, P. (2019) 'A panel analysis of Brazilian regional inequality', Environment and Planning A, 51(7):1558-1585.

Astorga, P. (2017) 'Real wages and skill premiums in Latin America, 1900-2011', Journal of Iberian and Latin American Economic History 35(3): 319-53.

Bengtsson, E. (2014) 'Do unions redistribute income from capital to labour? Union density and wage shares since 1960', Industrial Relations Journal 45: 389-408.

Bergeaud, A., Cette, G. and Lecat, R. (2016). 'Productivity Trends in Advanced Countries between 1890 and 2012', Review of Income and Wealth 62(3): 420-44.

Böckerman, P. and Maliranta, M. (2012) 'Globalization, creative destruction, and labour share change: evidence on the determinants and mechanisms from longitudinal plant-level data', Oxford Economic Papers 64(2): 259-80.

Boulhol, H., Dobbelaere, S. and Maioli, S. (2011) 'Imports as product and labour market discipline', British Journal of Industrial Relations 49(2): 331-61.

Brady, D. and Wallace, M. (2000) 'Spatialization, Foreign Direct Investment and Labor Outcomes in the American States, 1978-1996', Social Forces 79(1): 67 -105.

Bril-Mascarenhas, T. and Madariaga, A. (2019) 'Business Power and the Minimal State: The Defeat of Industrial Policy in Chile', Journal of Development Studies, 55(6):1047-1066

Campero, G. (1993) 'Los Empresarios Chilenos en el regimen militar y el post-plebiscito. In P. W. Drake and I. Jaksic (eds), El Deficil camino hacia la democracia en Chile, 1982-1990. Santiago: FLACSO.

Clark, D. T. (2017) 'Rethinking Chile's 'Chicago Boys': Neoliberal Technocrats or Revolutionary Vanguard?, Third World Quarterly, 38(6):1350-1365.

Constantine, C. (2017). 'Economic Structures, Institutions and Economic Performance', Journal of Economic Structures $6(2): 1-18$.

Constantine, C. and Khemraj, T. (2019). 'Geography, Economic Structures and Institutions: A Synthesis', Structural Change and Economic Dynamics 51:371-379.

Cooney, P. (2016) 'Reprimarization: Implications for the Environment and Development in Latin America: The Cases of Argentina and Brazil, Review of Radical Political Economics, 48(4):553-561.

Cowling, K. and Molho, I. (1982) 'Wage Share, Concentration and Unionism', The Manchester School 50(2): 99-115.

Daban, T. (2011) 'Strengthening Chile's Rule-based Fiscal Framework', IMF Working Paper, WP/11/17.

Darcillon, T. (2015) 'How does finance affect labor market institutions? An empirical analysis in 16 OECD countries', Socio-Economic Review 13: 477-504.

Davidson, J.E.H., et al., (1978) 'Econometric modelling of the aggregate time-series relationship between consumers' expenditure and income in the United Kingdom', Economic Journal 88: 661-92.

Davis-Hamel, A. (2012) 'Successful Neoliberalism?: State Policy, Poverty and Income Inequality in Chile', International Social Science Review, 87(3/4):79-101.

Dell'Aringa, C. and Pagani, L. (2007) 'Collective bargaining and wage dispersion in Europe', British Journal of Industrial Relations 45(1): 29-54.

Devicienti, F., Fanfani, B., and Maida, A. (2019) 'Collective bargaining and the evolution of wage inequality in Italy', British Journal of Industrial Relations 57(2): 377-407.

Dünhaupt, P. (2017) 'Determinants of Labour's income share in the era of financialisation', Cambridge Journal of Economics 41: 283-306.

DW (2019). 'South America's protests fueled by 'extreme' social inequality'. Accessed at: www.dw.com/en/south-americas-protests-fueled-by-extreme-social-inequality/a-50977566

Fichtenbaum, R. (2009) 'The impact of unions on labor's share of income: A time-series analysis', Review of Political Economy 21(4): 567-88.

Flaherty, E., and Riain, S.Ó. (2019) 'Labour's declining share of national income in Ireland and Denmark: the national specificities of structural change', Socio-Economic Review doi.org/10.1093/ser/mwy047 
Frieden, J. A. (1991) 'Debt, Development and Democracy: Modern Political Economy and Latin America, 1965-1985. Princeton, NJ: Princeton University Press.

Froud, J., Haslam, C., Johal, S. and Williams, K. (2000) 'Restructuring for shareholder value and its implications for labour', Cambridge Journal of Economics 24(6): 771-97.

Froud, J., Johal, S. and Williams, K. (2002) 'Financialisation and the coupon pool', Capital \& Class 26: 11951.

Gereffi, G., Humphrey, J. and Sturgeon, T. (2005) 'The governance of global value chains', Review of International Political Economy 12(1): 78-104.

Gonzalez, D. and McKinley, T. (1997) 'The Paradox of Narrowing Wage Differential and Widening Wage Inequality in Mexico', Development and Change, 28, 505-530.

Gospel, H and Pendleton, A. (2003) 'Finance, corporate governance and the management of labour: a conceptual and comparative analysis', British Journal of Industrial Relations 41(3): 481-509.

Grant, D.S. and Wallace, M. (1994) 'The political economy of manufacturing growth and decline across the American states, 1970-1985', Social Forces 73(1): 33-63.

Guschanski, A. and Onaran Ö. (2018) 'Determinants of the Wage Share: A Cross-country Comparison Using Sectoral Data', CESifo Forum 19: 44-54.

Guschanski, A. and Onaran, Ö. (2017) 'Why is the wage share falling in emerging economies? Industry level evidence' Greenwich Papers in Political Economy No 52.

Gygli, S., Haelg, F., Potrafke, N., and Sturm, J.E. (2019) 'The KOF globalisation index-revisited', The Review of International Organizations 1-32.

Hager, S.B. (2015) 'Corporate ownership of the public debt: mapping the new aristocracy of finance', SocioEconomic Review 13(3): 505-23.

Hancke, B. (2012) 'Where have all the wage shares gone? Trade unions, central banks and wage setting in the OECD', Mimeo, London School of Economics.

Harrison, A. (2002) 'Has globalization eroded Labor's share? Some cross-country evidence', NBER.

Hartmann, D., Jara-Figueroa, C., Guevara, M., Simoes, A., Hidalgo, C. (2016) 'The Structural Constraints of Income Inequality in Latin America', Integration and Trade 40(40):70-85.

Herman, A. and Klemm, A. (2017) 'Financial Deepening in Mexico', IMF Working Paper, WP/17/19.

Hicks, J.R. (1932) The Theory of Wages, London: Macmillan.

ILO (2008) 'Income Inequalities in the Age of Financial Globalization', World of Work Report, Geneva: ILO.

IMF (2017) 'Understanding the Downward Trend in Labor Income Shares, World Economic Outlook, Washington, DC: IMF.

Jayadev, A. (2007) 'Capital account openness and the Labour share of income', Cambridge Journal of Economics 31: 423-43

Kaplan, S. (2013) 'Globalization and Austerity Politics in Latin America'. New York, NY: Cambridge University Press.

Köhler, A., Guschanski, A. and Stockhammer, E. (2019) 'The impact of financialisation on the wage share: a theoretical clarification and empirical test', Cambridge Journal of Economics 43(4): 937-74.

Kollmeyer, C. and Peters, J. (2019) 'Financialization and the Decline of Organized Labor: A Study of 18 Advanced Capitalist Countries, 1970-2012', Social Forces 98(1): 1-30.

Krippner, G.R. (2005) 'The financialization of the American economy', Socio-economic Review 3: 173-208.

Kristal, T. (2010) 'Good times, bad times: Postwar labor's share of national income in capitalist democracies', American Sociological Review 75: 729-63.

Kurtz, M. (1999) 'Chile's Neoliberal Revolution: Incremental Decisions and Structural Transformation', Journal of Latin American Studies, 31, 399-427.

Kurtz, M. (2002) 'Understanding the Third World Welfare State after Neoliberalism: The Politics of Social Provision in Chile and Mexico', Comparative Politics, 34(3):293-313.

Langley, P. (2007) 'Uncertain Subjects of Anglo-American Financialization', Cultural Critique 65: 67-91.

Lapavitsas, C. and Mendieta-Muñoz, I. (2019) 'The historic rise of financial profits in the US economy', Journal of Post Keynesian Economics 42(3): 443-68.

Laurell, A. (2015) 'Three Decades of Neoliberalism in Mexico: The Destruction of Society', International Journal of Health Services, 45(2):246-264.

Lazonick, W. and O'Sullivan, M. (2000) 'Maximizing shareholder value: A new ideology for corporate governance', Economy and Society 29: 13-35. 
Leslie, D. and $\mathrm{Pu}, \mathrm{Y}$. (1996) 'What caused rising earnings inequality in Britain? Evidence from time series, 1970-1993', British Journal of Industrial Relations 34(1): 111-30.

Levine, R. (1997) 'Financial Development and Growth: Views and Agenda', Journal of Economic Literature, 35:688-726.

Lin, K.H. and Tomaskovic-Devey, D. (2013) 'Financialization and US income inequality, 1970-2008', American Journal of Sociology 118(5): 1284-329.

Madariaga, A. (2017) 'Mechanisms of Neoliberal Resilience: Exchange Rates and Industrial Policy in Chile and Estonia, Socio-Economic Review, 15, 637-660.

Martin, P. (2005). 'Comparative topographies of neoliberalism in Mexico', Environment and Planning A, 37: 203-220.

McGowan, C. (2019) 'Chile Protests: What Prompted the Unrest?', 30 ${ }^{\text {th }}$ October Aljazeera.

Meller, P. (1991) 'Adjustment and Social Costs in Chile During the 1980s', World Development, 19(11):15451561.

Meyer, B. (2019) 'Financialization, Technological Change, and Trade Union Decline', Socio-Economic Review 17(3): 477-502.

Morton, A. (2003) 'Structural Change and Neoliberalism in Mexico: Passive Revolution in the Global Political Economy', Third World Quarterly, 24(4):631-653.

Onaran, Ö. (2009) 'Wage share, globalization and crisis: the case of the manufacturing industry in Korea, Mexico and Turkey', International Review of Applied Economics 23(2): 113-34.

Onaran, Ö. and Galanis, G. (2014). Income Distribution and Growth: A Global Model. Environment and Planning A, 46(10), 2489-2513.

Ortiz, J. (2019). 'The Establishment of Neoliberalism in Mexico', PSL Quarterly Review, 72(289):167-184.

Palpacuer, F., Seignour, A. and Vercher, C. (2011) 'Financialisation, globalization and the management of skilled employees: towards a market-based HRM model in large corporations in France', British Journal of Industrial Relations 49(3): 560-82.

Peck, J. and Tickell, A. (2002) 'Neoliberalizing space'. Antipode, 34(3): 380-404.

Perreault, T. and Martin, P. (2005) 'Geographies of neoliberalism in Latin America' Environment and Planning A, 37(2):191-201.

Pontusson, J. (2013) 'Unionization, inequality and redistribution', British Journal of Industrial Relations 51(4): $797-825$.

Rodrik, D. (1997) Has Globalization Gone Too Far? Washington, DC: Institute for International Economics.

Rowthorn, R. (1995) Capital Formation and Unemployment, Oxford Review of Economic Policy, 11 (1):26-39.

Sanchez-Ancochea, D. (2019) 'The Surprising Reduction of Inequality During a Commodity Boom: What Do We Learn from Latin America?' Journal of Economic Policy Reform, 1-24.

Sargan, J.D. (1964) 'Wages and prices in the U.K.: a study in econometric methodology', in P.E. Hart et al. (Eds) Econometric Analysis for National Planning, London: Butterworth.

Silva Herzog, F. (2007) 'A la distancia recuerdos y testimonies, Mexico: Editorial Oceano.

Stockhammer, E. (2004) 'Financialisation and the slowdown of accumulation', Cambridge Journal of Economics 28: 719-41.

Stockhammer, E. (2015) 'Rising Inequality as a Cause of the Present Crisis', Cambridge Journal of Economics, 39(3):935-958.

Stockhammer, E. (2017) 'Determinants of the wage share: A panel analysis of advanced and developing economies', British Journal of Industrial Relations 55: 3-33.

Stolper, W. and Samuelson, P. (1941) 'Protection and Real Wages', Review of Economic Studies, 9:58-73.

Storm, S. and Naastepad, C. W. M. (2012) 'Macroeconomics Beyond the NAIRU', Harvard University Press.

Streeck, W. (2014) Buying Time: The Delayed Crisis of Democratic Capitalism, London, Verso.

Thompson, P. (2003) 'Disconnected capitalism: or why employers can't keep their side of the bargain', Work, Employment and Society 17(2): 359-78.

Weyland, K. (1999) 'Neoliberal Populism in Latin America and Eastern Europe', Comparative Politics, 31, 379-401.

Wood, J.D.G. (2017) 'The effects of the distribution of mortgage credit on the wage share: Varieties of residential capitalism compared', Comparative European Politics 15: 819-47. 


\section{Appendix}

Table A1: Descriptive statistics and Augmented Dickey-Fuller tests

\begin{tabular}{|c|c|c|c|c|c|c|c|}
\hline & Mean & Max & Min & Std. Dev. & $\begin{array}{c}\text { ADF } \\
\text { Levels }\end{array}$ & $\begin{array}{c}\text { ADF } \\
1^{\text {st }} \text { Diff. }\end{array}$ & Obs \\
\hline \multicolumn{8}{|l|}{ Chile } \\
\hline Wage Share & 45.53 & 65.17 & 38.32 & 6.66 & 0.49 & 0.00 & 32 \\
\hline Government Consumption & 11.47 & 15.78 & 9.67 & 1.45 & 0.59 & 0.00 & 32 \\
\hline Trade Openness & 59.02 & 80.79 & 39.87 & 10.02 & 0.73 & 0.00 & 32 \\
\hline Terms of Trade & 149.89 & 243.33 & 92.75 & 45.65 & 0.42 & 0.00 & 32 \\
\hline Private Debt & 65.85 & 102.23 & 41.05 & 18.71 & 0.96 & 0.00 & 32 \\
\hline Stocks Traded & 8.78 & 26.51 & 0.51 & 7.49 & 0.35 & 0.00 & 32 \\
\hline Capital Intensity & 25.61 & 46.00 & 21.00 & 9.49 & 1.00 & 0.00 & 32 \\
\hline Manufacturing Share & 17.14 & 22.96 & 10.77 & 3.36 & 0.11 & 0.00 & 32 \\
\hline Strike Activity & 127.66 & 247.00 & 38.00 & 59.13 & 0.66 & 0.00 & 32 \\
\hline Public Debt & 46.00 & 165.55 & 3.89 & 47.99 & 0.21 & 0.00 & 32 \\
\hline KOF Index & 62.80 & 78.34 & 50.97 & 10.83 & 0.99 & 0.00 & 32 \\
\hline Polity2 Score & 4.69 & 10.00 & -7.00 & 6.76 & 0.38 & 0.00 & 32 \\
\hline FDI Inflows & 4.61 & 11.65 & 0.40 & 2.98 & 0.24 & 0.00 & 32 \\
\hline Nominal Exchange Rate & 383.87 & 691.40 & 39.00 & 194.82 & 0.40 & 0.00 & 32 \\
\hline Natural Resources Rents & 10.23 & 21.39 & 4.80 & 4.83 & 0.50 & 0.00 & 32 \\
\hline \multicolumn{8}{|l|}{ Mexico } \\
\hline Wage Share & 49.59 & 55.36 & 45.44 & 2.42 & 0.43 & 0.00 & 32 \\
\hline Government Consumption & 9.59 & 11.92 & 8.12 & 1.11 & 0.70 & 0.00 & 32 \\
\hline Trade Openness & 42.73 & 63.47 & 22.12 & 13.28 & 0.98 & 0.00 & 32 \\
\hline Terms of Trade & 128.18 & 306.56 & 90.32 & 59.29 & 0.00 & 0.00 & 32 \\
\hline Private Debt & 18.11 & 30.89 & 11.21 & 5.01 & 0.82 & 0.00 & 32 \\
\hline Stocks Traded & 6.49 & 12.50 & 0.42 & 3.63 & 0.47 & 0.00 & 32 \\
\hline Capital Intensity & 52.57 & 60.00 & 46.00 & 4.38 & 0.51 & 0.00 & 32 \\
\hline Manufacturing Share & 18.14 & 22.10 & 15.10 & 1.80 & 0.20 & 0.00 & 32 \\
\hline Strike Activity & 225.53 & 1925.00 & 11.00 & 423.25 & 0.00 & 0.00 & 32 \\
\hline Public Debt & 46.84 & 78.14 & 30.91 & 12.06 & 0.63 & 0.00 & 32 \\
\hline KOF Index & 55.32 & 67.19 & 44.79 & 7.57 & 0.98 & 0.00 & 32 \\
\hline Polity2 Score & 3.19 & 8.00 & -3.00 & 4.65 & 0.77 & 0.00 & 32 \\
\hline FDI Inflows & 1.96 & 3.97 & 0.80 & 0.86 & 0.86 & 0.00 & 32 \\
\hline Nominal Exchange Rate & 6.14 & 13.51 & 0.02 & 4.70 & 0.98 & 0.00 & 32 \\
\hline Natural Resources Rents & 5.75 & 13.40 & 1.65 & 2.96 & 0.13 & 0.00 & 32 \\
\hline
\end{tabular}


Table A3: Robustness estimations

\begin{tabular}{|c|c|c|c|c|c|c|c|c|}
\hline & \multicolumn{4}{|c|}{ Chile } & \multicolumn{4}{|c|}{ Mexico } \\
\hline & (8) & (9) & (10) & (11) & (8) & (9) & (10) & (11) \\
\hline \multicolumn{9}{|l|}{ Long-run coefficients } \\
\hline Wage Share $_{t-1}$ & $-1.346^{* * *}$ & $-1.331 * * *$ & $-1.514 * * *$ & $-1.224 * *$ & $-0.508^{*}$ & -0.362 & $-0.568 * *$ & -0.408 \\
\hline Government Consumption $_{t-1}$ & $1.872 * * *$ & $1.720 * * *$ & $1.627 * * *$ & $1.747 * * *$ & $0.635^{* *}$ & $0.588 *$ & $0.701 * * *$ & $0.618^{* *}$ \\
\hline Trade Openness $_{t-1}$ & $1.030^{* *}$ & $1.061 * * *$ & 0.917 & $1.103 * *$ & $-1.004^{*}$ & -0.682 & $-1.022 * * *$ & -0.803 \\
\hline Terms of Trade ${ }_{t-1}$ & 0.604 & 0.475 & 0.868 & $0.796 * *$ & $-1.131 * *$ & $-1.159 * *$ & $-0.787 *$ & $-1.134 * *$ \\
\hline Private Debt $t_{t-1}$ & $-1.776^{* * *}$ & -1.548 & $-1.647 * * *$ & $-1.841 * *$ & 0.153 & 0.199 & -0.097 & 0.130 \\
\hline Stocks Traded $_{t-1}$ & -0.081 & -0.417 & -0.696 & -0.366 & -0.157 & -0.222 & -0.071 & -0.168 \\
\hline FDI Inflows $t-1$ & -0.259 & & & & 0.193 & & & \\
\hline Nominal Exchange Rate ${ }_{t-1}$ & & -0.267 & & & & -0.126 & & \\
\hline Natural Resources Rents $t-1$ & & & 0.102 & & & & $-0.612 * *$ & \\
\hline Codelco Law Dummy & & & & 0.064 & & & & \\
\hline NAFTA Dummy & & & & & & & & -0.007 \\
\hline$R^{2}$ & 0.89 & 0.90 & 0.89 & 0.88 & 0.72 & 0.72 & 0.79 & 0.76 \\
\hline$B G$ & 0.63 & 0.88 & 0.79 & 0.78 & 0.02 & 0.09 & 0.00 & 0.02 \\
\hline Harvey & 0.18 & 0.35 & 0.25 & 0.20 & 0.54 & 0.02 & 0.25 & 0.17 \\
\hline Obs & 31 & 31 & 31 & 31 & 31 & 31 & 31 & 31 \\
\hline
\end{tabular}

